\title{
On the Issue of National Projects of the Russian Federation in Achieving the Sustainable Development Goals
}

\author{
Pavel Letov*, Natalya Istomina, Nadezhda Goncharova
}

\author{
Ural State University of Economics, Yekaterinburg, Russia \\ ${ }^{*}$ Corresponding author. Email: lep.7@mail.ru
}

\begin{abstract}
The essence of this article is to analyze the role of national projects of the Russian Federation in the process of achieving the UN sustainable development goals. The achievements of the Russian Federation in the process of implementing national projects, solving problems formed within the framework of sustainable development goals, and developing project management in Russia testify to the relevance of the issue of the role of national projects of the Russian Federation in achieving sustainable development goals. Russian program and strategic documents, including passports of national projects, are characterized by a high degree of integration with the goals of sustainable development. The article emphasizes that it is necessary to provide high-quality mechanisms for the implementation of national projects and improve the processes of their financing to solve problems within the framework of sustainable development goals. The main hypothesis is based on the fact that all the goals of sustainable development in the Russian Federation are achieved through the implementation of national projects. The key conclusions on the implementation of sustainable development goals in the Russian Federation are identified and the key role of national projects in this process is reflected. The article presents measures that determine measures to integrate national projects into sustainable development goals for future periods.
\end{abstract}

Keywords: national projects, sustainable development, sustainable development goals, financing of national projects, United Nations, national development goals, strategic development objectives, project management, project financing.

\section{INTRODUCTION}

2015 became a kind of challenge for the world and at the same time a grandiose step towards uniting all countries to preserve the planet for future generations. The fact is that in August 2015, 193 Member States of the United Nations reached agreement on a new agenda for sustainable development. As early as the next month, the UN adopted the agenda "Transforming our world: the 2030 Agenda for Sustainable Development", which includes 17 sustainable development goals [1].

The Sustainable Development Goals are a declaration for all countries in the issue of uniting for sustainable development - the creation and implementation of a set of measures in three areas: economic development, social integration and environmental protection. Despite the ambitiousness of the sustainable development goals, the activities planned by the UN can have a significant impact on the fight against inequality, climate change and the solution of key problems in the most important areas of human life: education, health care, social support, etc.

Within the framework of the sustainable development goals, it is planned to solve 169 tasks that have their own activities and recommendations for their implementation.

Obviously, such ambitious tasks cannot be solved without appropriate funding and building modern models of project management.

Since 2019, in the Russian Federation, national projects have been implemented in key areas. National projects are considered to have goals that go beyond the sustainable development agenda and are even more difficult to implement than the sustainable development goals. 
The first attempts to transition the Russian economy to project management were made long before the national projects, which we are used to seeing them now, and the sustainable development goals declared by the UN. The first instrument for solving target problems was the federal target programs, adopted for the first time in 2002. However, the starting point for national projects, which we are used to seeing them now, was the signing by the President of Russia Vladimir Putin of the Decree of the President of the Russian Federation dated May 7, 2018 No. 204 "On national goals and strategic objectives of the development of the Russian Federation for the period up to 2024", which established a list of goals and objectives to be achieved by the Government of the Russian Federation by 2024 [2].

The purpose of this work is to build relationships between national projects of the Russian Federation and the UN sustainable development goals, analyze the role of national projects in achieving sustainable development goals, assess the effectiveness of measures developed within the framework of national projects and sustainable development goals, and identify problems and prospects in integrating national development goals Of the Russian Federation and the Sustainable Development Goals.

\section{MATERIALS AND METHODS}

The methodological basis of the study is the regulatory legal acts of the Russian Federation that regulate the implementation and financing of national projects in the Russian Federation, research materials of authoritative economists on the implementation and assessment of the effectiveness of financing national projects. In addition, the work analyzes the works of economists in the field of sustainable development and project management in a national and international context.

\section{RESULTS AND DISCUSSION}

Russia has achieved the greatest results in several sustainable development goals [3]. Among them:

- Goal 1: No poverty;

- Goal 4: Quality education;

- Goal 8: Decent work and economic growth.

Table 1 shows in more detail Russia's contribution to the sustainable development agenda.

\section{CONCLUSION}

Speaking about the connection between the national projects of the Russian Federation and the sustainable development goals, it should be noted that the goals of sustainable development are increasingly integrated into the strategic and program documents of the Russian Federation every year. Today, all national projects of the Russian Federation have a direct impact on the achievement of sustainable development goals. As a UN member state, Russia is actively involved in achieving the goals formed in the 2030 Agenda.

Sustainable development is not a new topic for the Russian state [16-23]. Back in 1996, by Presidential Decree No. 440 of April 1, 1996, the Concept of the Russian Federation's Transition to Sustainable Development was adopted. The document established that the Government of the Russian Federation should be guided by the provisions of the Concept when developing forecasts and programs of socio-economic development, preparing regulatory legal acts, making economic and other decisions. These provisions confirm the thesis that the implementation of measures aimed at achieving sustainable development was carried out in the Russian Federation long before the formulation of sustainable development goals in the form in which we see them now [24].

National projects adopted in 2018 are able to solve most of the tasks facing states within the framework of the sustainable development goals. Only 12 national projects enshrined in the Decree of the President of the Russian Federation dated June 7, 2018 No. 204 "On national goals and strategic objectives of the development of the Russian Federation for the period up to 2024" and a comprehensive plan for the modernization and expansion of the trunk infrastructure affect the solution of 107 out of 169 tasks of the goals sustainable development [2].

In addition to government bodies, other stakeholders, including commercial and noncommercial organizations, state corporations, budgetary institutions and society, take part in achieving sustainable development goals.

In the future, with the emergence of new national projects, including the Comprehensive Program "Development of Engineering, Technologies and Scientific Research in the Use of Atomic Energy in the Russian Federation for the Period until 2024" and the national project being developed and planned for approval in the near future "Tourism and the hospitality industry", Russia will be able to render even greater assistance to the world community in solving the problems facing all mankind. 
Table 1. Russian measures to achieve sustainable development goals and their relationship with national projects of the Russian Federation.

\begin{tabular}{|c|c|c|}
\hline $\begin{array}{l}\text { Sustainable } \\
\text { Development } \\
\text { Goal }\end{array}$ & Key Takeaways to Achieve the Goal & Connection with national projects \\
\hline $\begin{array}{l}\text { Goal 1: No } \\
\text { poverty }\end{array}$ & $\begin{array}{l}\text { Russia has achieved the goal of eliminating extreme } \\
\text { poverty. By 2024, it is planned to reduce the poverty by } \\
2 \text { times compared to } 2018 \text { (in } 2018 \text {, the share of the } \\
\text { population with incomes below the minimum wage is } \\
12.6 \% \text { ) [4] }\end{array}$ & $\begin{array}{l}\text { The achievement of the goal will be facilitated } \\
\text { primarily by the national projects } \\
\text { "Demography" and "Labor productivity and } \\
\text { employment support" }\end{array}$ \\
\hline $\begin{array}{l}\text { Goal 2: Zero } \\
\text { hunger }\end{array}$ & $\begin{array}{l}\text { The achievement of the goal in Russia is facilitated by } \\
\text { the development of rural infrastructure, the reduction of } \\
\text { trade restrictions and the implementation of } \\
\text { comprehensive strategic programs }\end{array}$ & $\begin{array}{l}\text { The national project "International Cooperation } \\
\text { and Export" will contribute to the development } \\
\text { of agriculture and the establishment of } \\
\text { cooperation in this area }\end{array}$ \\
\hline $\begin{array}{l}\text { Goal 3: Good } \\
\text { health and well- } \\
\text { being }\end{array}$ & $\begin{array}{l}\text { If in } 2010 \text { the mortality rate in Russia was } 14.2 \text { people. } \\
\text { per } 1,000 \text { people, then in } 2019 \text { this figure dropped to } \\
12.3 \text { people. However, due to the pandemic in } 2020 \text {, the } \\
\text { figure exceeded the values of } 2010 \text { and amounted to } \\
14.5 \text { people. [5] Life expectancy in Russia is also } \\
\text { showing significant growth. The key measures to } \\
\text { achieve the goal are the development of the health care } \\
\text { system, the fight against diseases, the expansion of } \\
\text { infrastructure and the filling of the health care system } \\
\text { with a qualified workforce }\end{array}$ & $\begin{array}{l}\text { The national project "Health" will help to } \\
\text { achieve the goal, which sets the goal of } \\
\text { achieving a life expectancy of } 80 \text { years by } \\
2030 \text {. Also, the achievement of the goal is } \\
\text { facilitated by the national project } \\
\text { "Demography", in particular the federal project } \\
\text { "Sport is the norm of life" in its composition }\end{array}$ \\
\hline $\begin{array}{l}\text { Goal 4: Quality } \\
\text { education }\end{array}$ & $\begin{array}{l}\text { In the Russian Federation, free and high-quality } \\
\text { education is guaranteed by the Constitution of Russia. In } \\
\text { addition to national projects, there are a number of other } \\
\text { program documents. }\end{array}$ & $\begin{array}{l}\text { A special role is assigned to the national } \\
\text { projects "Education" and "Science and } \\
\text { Universities" }\end{array}$ \\
\hline $\begin{array}{l}\text { Goal 5: Gender } \\
\text { equality }\end{array}$ & $\begin{array}{l}\text { As in the case of education, gender equality is } \\
\text { guaranteed by the Russian Constitution. According to } \\
\text { the UN, Russia is among the countries with a very high } \\
\text { indicator of the level of human development ( } 0.824 \text { in } \\
2019 \text { ), and for women this indicator is equal to or } \\
\text { exceeds that for men [6]. To achieve this goal, Russia } \\
\text { has a National Action Strategy for Women for } 2017- \\
2022, \text { which is aimed, among other things, at reducing } \\
\text { the gender pay gap }\end{array}$ & $\begin{array}{l}\text { The federal project "Promotion of the } \\
\text { employment of women - the availability of } \\
\text { preschool education for children" was created }\end{array}$ \\
\hline $\begin{array}{l}\text { Goal 6: Clean } \\
\text { water and } \\
\text { sanitation }\end{array}$ & $\begin{array}{l}\text { According to data for } 2018,90.3 \% \text { of Russian } \\
\text { households are provided with central water supply, } \\
\text { which is } 3.6 \% \text { higher than the level of } 2014.77 .4 \% \text { of } \\
\text { the population had access to sewerage in } 2018 \text { ( } 4.4 \% \\
\text { more than in 2014) [3] }\end{array}$ & $\begin{array}{l}\text { The national project "Housing and Urban } \\
\text { Environment", in particular the federal project } \\
\text { "Clean Water", will contribute to the } \\
\text { achievement of this goal, within the framework } \\
\text { of which it is planned to provide high-quality } \\
\text { drinking water from central water supply } \\
\text { systems to } 90.8 \% \text { of the population by } 2024 \\
\text { (against } 87.5 \% \text { for December } 31,2017 \text { ) }\end{array}$ \\
\hline $\begin{array}{l}\text { Goal 7: } \\
\text { Affordable and } \\
\text { clean energy }\end{array}$ & $\begin{array}{l}\text { Russia is a state with a high level of development of the } \\
\text { energy industry and infrastructure. Already in } 2018 \text {, } \\
100 \% \text { of the population had access to electricity, and in } \\
2020 \text { Russia ranked } 7 \text { th in terms of ease of connection to } \\
\text { the power supply system from } 190 \text { countries in the } \\
\text { Doing Business } 2020 \text { rating [7]. In addition to the } \\
\text { comprehensive program for the development of the } \\
\text { nuclear industry in Russia, the Doctrine of Ensuring the } \\
\text { Energy Security of the Russian Federation and the State } \\
\text { Program "Development of Energy" }\end{array}$ & $\begin{array}{l}\text { In 2020, Russia launched the Comprehensive } \\
\text { Program "Development of equipment, } \\
\text { technologies and research. }\end{array}$ \\
\hline
\end{tabular}


Table 1. Continued

\begin{tabular}{|c|c|c|}
\hline $\begin{array}{c}\text { Sustainable } \\
\text { Development } \\
\text { Goal } \\
\end{array}$ & Key Takeaways to Achieve the Goal & Connection with national projects \\
\hline $\begin{array}{l}\text { Goal 8: Decent } \\
\text { work and } \\
\text { economic } \\
\text { growth }\end{array}$ & $\begin{array}{l}\text { Economic growth is impossible without an increase } \\
\text { in the growth rate of GDP and the level of citizens' } \\
\text { incomes. In August } 2021 \text {, data emerged that the } \\
\text { Russian economy had grown for the first time since } \\
\text { the start of the pandemic. Russian GDP in the } 2 \text { nd } \\
\text { quarter of } 2021 \text { grew by } 10.3 \% \text { in annual terms (the } \\
\text { maximum growth in a quarter since } 2000 \text { ). The last } \\
\text { time the economy showed growth a year ago - in the } \\
\text { pre-pandemic first quarter of } 2020 \text { [5] }\end{array}$ & $\begin{array}{l}\text { The achievement of this goal in Russia is } \\
\text { significantly influenced by the national projects } \\
\text { "Labor productivity and employment support", } \\
\text { "Small and medium-sized enterprises and support } \\
\text { of individual entrepreneurial initiative" and } \\
\text { "Science and Universities" }\end{array}$ \\
\hline $\begin{array}{l}\text { Goal 9: Industry, } \\
\text { Innovation and } \\
\text { Infrastructure }\end{array}$ & $\begin{array}{l}\text { The priority sectors of infrastructure development in } \\
\text { Russia are transport, energy, communications, } \\
\text { manufacturing and innovation. In Russia, the } \\
\text { infrastructure is constantly being improved and } \\
\text { modernized, and access to it is provided for all } \\
\text { segments of the population. So, in August } 2021 \text {, an } \\
\text { increase in production was recorded in the field of } \\
\text { passenger turnover (+250\%), cargo turnover (+ } \\
9.9 \%) \text {, etc. [5] }\end{array}$ & $\begin{array}{l}\text { The achievement of the goal is facilitated by the } \\
\text { National Project "Safe High-Quality Roads", the } \\
\text { National Program "Digital Economy of the } \\
\text { Russian Federation" }\end{array}$ \\
\hline $\begin{array}{l}\text { Goal 10: } \\
\text { Reduced } \\
\text { inequality }\end{array}$ & $\begin{array}{l}\text { Russia is taking a set of measures aimed at reducing } \\
\text { inequality both within the country and abroad within } \\
\text { the framework of development assistance programs. } \\
\text { In } 2020 \text {, the Gini coefficient (income concentration } \\
\text { index) was } 0.406 \text {, against } 0.412 \text { in } 2015 \text { and } 0.421 \\
\text { in } 2010 \text { (the lower the coefficient, the higher the } \\
\text { equality indicator) [5] }\end{array}$ & $\begin{array}{l}\text { The national project "Demography" is intended to } \\
\text { have a positive impact on the achievement of the } \\
\text { goal (for example, through payments to families at } \\
\text { the birth of children). The national program } \\
\text { "Digital Economy of the Russian Federation" and } \\
\text { the national project "Housing and Urban } \\
\text { Environment" (in terms of an accessible } \\
\text { environment and the formation of a comfortable } \\
\text { urban environment) will also contribute to } \\
\text { achieving this goal }\end{array}$ \\
\hline $\begin{array}{l}\text { Goal 11: } \\
\text { Sustainable } \\
\text { cities and } \\
\text { communities }\end{array}$ & $\begin{array}{l}\text { This goal is related to global problems that are } \\
\text { reflected in urban life. These include inequality, i.e. } \\
\text { the number of people living in slums, energy } \\
\text { consumption, environmental protection, safety, etc. } \\
\text { The solution to these problems is reflected in the } \\
\text { program documents of the Russian Federation. It is } \\
\text { worth noting that in order to reduce inequality, it is } \\
\text { necessary to provide urban residents with affordable } \\
\text { housing. And according to this indicator, Russia is } \\
\text { making significant progress. For example, since } \\
2008 \text {, the housing affordability index has almost } \\
\text { doubled, from } 66 \% \text { to } 128 \% \text { in } 2018 \text {. The housing } \\
\text { affordability ratio has also dropped significantly (if } \\
\text { in } 2008 \text { it took a family } 5.3 \text { years to acquire a } \\
\text { standard apartment of } 54 \text { sq. M, in } 2019 \text { it took only } \\
3.2 \text { years) [8] }\end{array}$ & $\begin{array}{l}\text { The national projects "Housing and Urban } \\
\text { Environment" (in terms of reducing mortgage } \\
\text { rates and increasing the volume of housing } \\
\text { construction) and "Ecology" (in terms of } \\
\text { improving the environmental situation in cities and } \\
\text { towns) }\end{array}$ \\
\hline $\begin{array}{l}\text { Goal 12: } \\
\text { Responsible } \\
\text { consumption and } \\
\text { production }\end{array}$ & $\begin{array}{l}\text { The key problem associated with the goal is, oddly } \\
\text { enough, ecology. And Russia is showing significant } \\
\text { success in this regard. From } 2015 \text { to } 2018 \text {, the } \\
\text { amount of hazard class I waste generated annually in } \\
\text { Russia decreased by } 4 \text { times (from } 80 \text { to } 20 \\
\text { thousand tons) [9]. Infrastructure for separate waste } \\
\text { collection is being created in large cities; at the end } \\
\text { of } 2020 \text {, separate waste collection was introduced in } \\
45 \text { regions of Russia [10] }\end{array}$ & $\begin{array}{l}\text { National projects "Labor productivity and } \\
\text { employment support", as well as "Ecology" }\end{array}$ \\
\hline
\end{tabular}


Table 1. Continued

\begin{tabular}{|c|c|c|}
\hline $\begin{array}{l}\text { Sustainable } \\
\text { Development } \\
\text { Goal }\end{array}$ & Key Takeaways to Achieve the Goal & Connection with national projects \\
\hline $\begin{array}{l}\text { Goal 13: } \\
\text { Climate action }\end{array}$ & $\begin{array}{l}\text { In 2019, Russia adopted the Paris Climate } \\
\text { Agreement, which provides for a set of measures } \\
\text { and instruments to combat climate change. }\end{array}$ & $\begin{array}{l}\text { In order to combat climate change, Russia is } \\
\text { carrying out a set of measures reflected in the } \\
\text { national project "Ecology" }\end{array}$ \\
\hline $\begin{array}{l}\text { Goal 14: Life } \\
\text { below water }\end{array}$ & $\begin{array}{l}\text { Russia is successfully implementing program and } \\
\text { strategic documents related to the careful treatment } \\
\text { of marine resources and the World OceanIn } 2020 \text {, } \\
\text { the area of specially protected natural areas in } \\
\text { marine areas amounted to } 21.2 \text { million hectares, } \\
\text { which is almost } 2 \text { times more than in } 2016 \text { (10.9 } \\
\text { million hectares) [12]. The biodiversity of marine } \\
\text { fish has also increased (from } 400 \text { to } 1,500 \text { species } \\
\text { over the period from } 2015 \text { to } 2018 \text { ) [3] }\end{array}$ & $\begin{array}{l}\text { The achievement of the goal may be influenced } \\
\text { by the activities of the national project "Ecology" } \\
\text { related to the disposal and recycling of garbage, } \\
\text { since almost all garbage eventually ends up in the } \\
\text { World Ocean. The national project "Science and } \\
\text { Universities" will also have an impact on the } \\
\text { achievement of the goal (within the framework of } \\
\text { the national project, it is planned to build two } \\
\text { research vessels intended for oceanological } \\
\text { research anywhere in the World Ocean) [12] }\end{array}$ \\
\hline $\begin{array}{l}\text { Goal 15: Life on } \\
\text { land }\end{array}$ & $\begin{array}{l}\text { In 2021, Russian ecosystems underwent a serious } \\
\text { test - the largest forest fires in world history [13]. } \\
\text { One of the effective measures in the fight against } \\
\text { climate change (which corresponds to Goal 13) and } \\
\text { the restoration of terrestrial ecosystems is the All- } \\
\text { Russian action "Save the Forest", organized by the } \\
\text { Ministry of Natural Resources of Russia. As part of } \\
\text { the campaign, } 80 \text { million trees were planted in } \\
2018-2020,70 \text { million trees are planned to be } \\
\text { planted in } 2021 \text {, and } 5 \text { billion by } 2030 \text {. The state } \\
\text { program "Development of forestry" and the } \\
\text { Strategy for the development of the forestry } \\
\text { complex of the Russian Federation are also aimed } \\
\text { at preserving forests. until } 2030\end{array}$ & $\begin{array}{l}\text { It is planned to involve } 1.5 \text { million people in } \\
\text { measures for the protection, protection and } \\
\text { reproduction of forests by } 2024 \text { (despite the fact } \\
\text { that in } 2020 \text { this figure was only } 500 \text { thousand } \\
\text { people). Also, it is planned to increase the ratio of } \\
\text { the area of reforestation and afforestation to the } \\
\text { area of felled and dead forest stands from } 62.3 \% \\
\text { in } 2018 \text { to } 100 \% \text { by } 2024 \text {. }\end{array}$ \\
\hline $\begin{array}{l}\text { Goal 16: Peace, } \\
\text { justice and } \\
\text { strong } \\
\text { institutions }\end{array}$ & $\begin{array}{l}\text { In accordance with the Constitution, Russia is a } \\
\text { state governed by the rule of law, in which the } \\
\text { highest value is a person, his rights and freedoms. } \\
\text { One of the key mechanisms for increasing the } \\
\text { efficiency of public administration institutions is } \\
\text { the development of a system of multifunctional } \\
\text { centers, the satisfaction of which with citizens is } \\
96.6 \%[14] \text {. }\end{array}$ & $\begin{array}{l}\text { A set of measures reflected in the national } \\
\text { program "Digital Economy of the Russian } \\
\text { Federation" is aimed at achieving this goal }\end{array}$ \\
\hline $\begin{array}{l}\text { Goal 17: } \\
\text { Partnership for } \\
\text { the goals }\end{array}$ & $\begin{array}{l}\text { The state on a permanent basis finances projects } \\
\text { and programs related to international development } \\
\text { assistance. From } 2014 \text { to } 2020 \text { alone, more than } \$ \\
5.5 \text { billion was allocated for these purposes. The } \\
\text { funds are provided as part of the implementation of } \\
\text { Agreements on the use of foreign countries' debts } \\
\text { to the Russian Federation for the purpose of } \\
\text { financing development projects [15] }\end{array}$ & $\begin{array}{l}\text { In addition to financial support, the achievement } \\
\text { of the goal is directly influenced by the national } \\
\text { project "International cooperation and export" }\end{array}$ \\
\hline
\end{tabular}

\section{REFERENCES}

[1] Transforming Our World: The 2030 Agenda for Sustainable Development. UN, 2015.

[2] Decree of the President of the Russian Federation of May 7, 2018 No. 204 "On national goals and strategic objectives of the development of the
Russian Federation for the period up to 2024". http://www.consultant.ru.

[3] Voluntary National Review of the Implementation of the 2030 Agenda for Sustainable Development, 2020 . 
[4] Unified plan to achieve the national development goals of the Russian Federation for the period up to 2024, 2019.

[5] Federal State Statistics Service. https://rosstat.gov.ru.

[6] Human Development Report 2020, United Nations Development Program, Conceição Pedro, United Nation, 2020.

[7] Ministry of Energy of the Russian Federation. https://minenergo.gov.ru.

[8] Institute for Urban Economics, https://urbaneconomics.ru.

[9] State report "On the state and protection of the environment of the Russian Federation in 2017", 2018.

[10] All-Russian Popular Front, https://onf.ru.

[11] Ministry of Natural Resources and Environment of the Russian Federation, https://www.mnr.gov.ru.

[12] Government of the Russian Federation, https://www.government.ru.

[13] The Washington https://www.washingtonpost.com.

[14] Constitution of the Russian Federation, http://www.consultant.ru.

[15] Ministry of Finance of the Russian Federation, https://minfin.gov.ru.

[16] G.F. Balakina, Specifics of Forming a Regional Socioeconomic Development Strategy in Context of Modernization, Regional Research of Russia, 5(3) (2015) pp. 270-275.

[17] E. Katherine, Kemsley, Marianne Defernez, Federico Marini, Multivariate statistics: Considerations and confidences in food authenticity problems, Food Control, 105 (2019) pp. 102-112.

[18] N. A Goncharova, N. V. Merzlyakova, Investigation of import substitution and expansion impact in Russian foreign economic practice by supply chain strategy, International Journal of Supply Chain Management, 9(2) (2020) pp. 772778.

[19] Jason DeBacker, Bradley T. Heim, Anh Tran, Importing corruption culture from overseas: Evidence from corporate tax evasion in the United States, Journal of Financial Economics, 117(1) (2015) pp. 122-138.

[20] Joanne Swaffield, David Evans, Daniel Welch, Profit, reputation and 'doing the right thing': Convention theory and the problem of food waste in the UK retail sector, Geoforum, 89 (2018) pp. 43-51.

[21] Kowsar Yousefi, Mohammad Vesal, Hanifa Pilvar, Import tax evasion and avoidance: Evidence from Iran. The Quarterly Review of Economics and Finance, 2019.

[22] Niccolò Pisani, Arno Kourula, Ans Kolk and Renske Meijer, how global is international CSR research? Insights and recommendations from a systematic review, Journal of World Business, 52 (2017) pp. 591-614.

[23] L. Yintsze, features of evaluating the effectiveness of investment Russian-Chinese international projects, Economy and business: theory and practice, 2019.

[24] Decree of the President of the Russian Federation of April 1, 1996 No. 440 "On the Concept of the Transition of the Russian Federation to Sustainable Development", http://www.consultant.ru. 